\title{
On the Classification and Grading of Medulloepithelioma of the Eye
}

\author{
Robert M. Verdijk \\ Section of Ophthalmic Pathology, Department of Pathology, Erasmus MC University Medical Center, Rotterdam, \\ The Netherlands
}

\section{Key Words}

Eye $\cdot$ Medulloepithelioma $\cdot$ Iris · Ciliary body $\cdot$ Retina .

Grading $\cdot$ Classification

\begin{abstract}
Medulloepithelioma is a rare congenital tumor of the ciliary body and iris. The current classification and grading of medulloepithelioma shows inconsistencies and does not reflect clinical behavior. This position paper discusses the backgrounds of the current classification and intends to initiate a discussion on an alternative classification and grading scheme.

(๑) 2016 The Author(s)

Published by S. Karger AG, Basel
\end{abstract}

Recently, I had to produce the pathology report of a case of intraocular medulloepithelioma, a rare congenital tumor of the ciliary body and iris. In the preparation of a histopathological diagnosis, my attention was brought to inconsistencies in the WHO classification scheme. The most recent WHO fascicle on the international histological classification of tumors of the eye and its adnexa [1] offers two separate classifying entities of medulloepithelioma: teratoid or nonteratoid, both in a benign and a

\section{KARGER}

E-Mail karger@karger.com www.karger.com/oop

\section{C) 2016 The Author(s) \\ Published by S. Karger AG, Basel 2296-4681/16/0023-0190\$39.50/0}

This article is licensed under the Creative Commons AttributionNonCommercial-NoDerivatives 4.0 International License (CC BY NC-ND) (http://www.karger.com/Services/OpenAccessLicense) Usage and distribution for commercial purposes as well as any distribution of modified material requires written permission. malignant variant. The fascicle defines teratoid variants to contain cartilage and, less commonly, glial tissue and/ or skeletal muscle. However, how to make the distinction between benign and malignant is not addressed.

The name of medulloepithelioma derives from the histological resemblance of the tumor to the neuroepithelium of the embryonic neural tube and was chosen by Grinker [2] because of the histopathological resemblance to an even rarer form of medulloeptihelioma of the brain described by Bailey and Cushing [3]. In the most recent revision of the WHO classification of tumors of the central nervous system, to be published in 2016 [4], mesenchymal elements in medulloepithelioma are described to range from a prominent vascular and fibrous connective tissue stroma to areas of cartilage, bone and striated muscle. These mesenchymal elements are interpreted as multiple lines of differentiation within one tumor entity and are as such not reflected in the classifying diagnosis of intracerebral medulloepithelioma. The same line of reasoning could be followed for intraocular medulloepithelioma. The cerebral medulloepithelioma is often large at diagnosis and is by definition classified as a high-grade malignant tumor although long-term survivors have been described. Only recently has the demonstration of molecular diversity at the cytogenetic and epigenetic lev- 


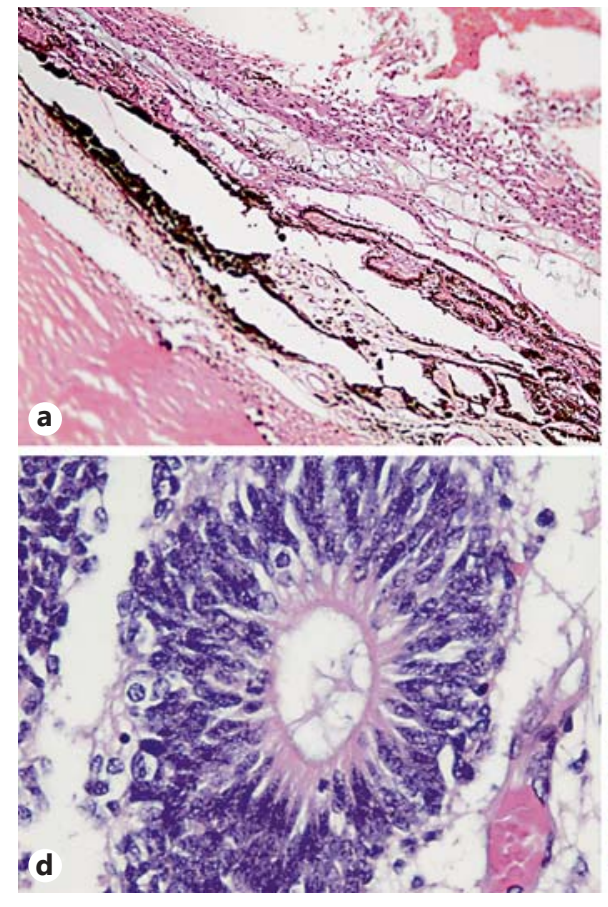

Fig. 1. Proposed histological parameters for grading of medulloepithelioma of the eye. a Grade I (benign) medulloepithelioma. Original magnification $\times 100$. b Grade II medulloepithelioma, local invasion. Original magnification $\times 25$. c-e Pleomorphism, mitotic
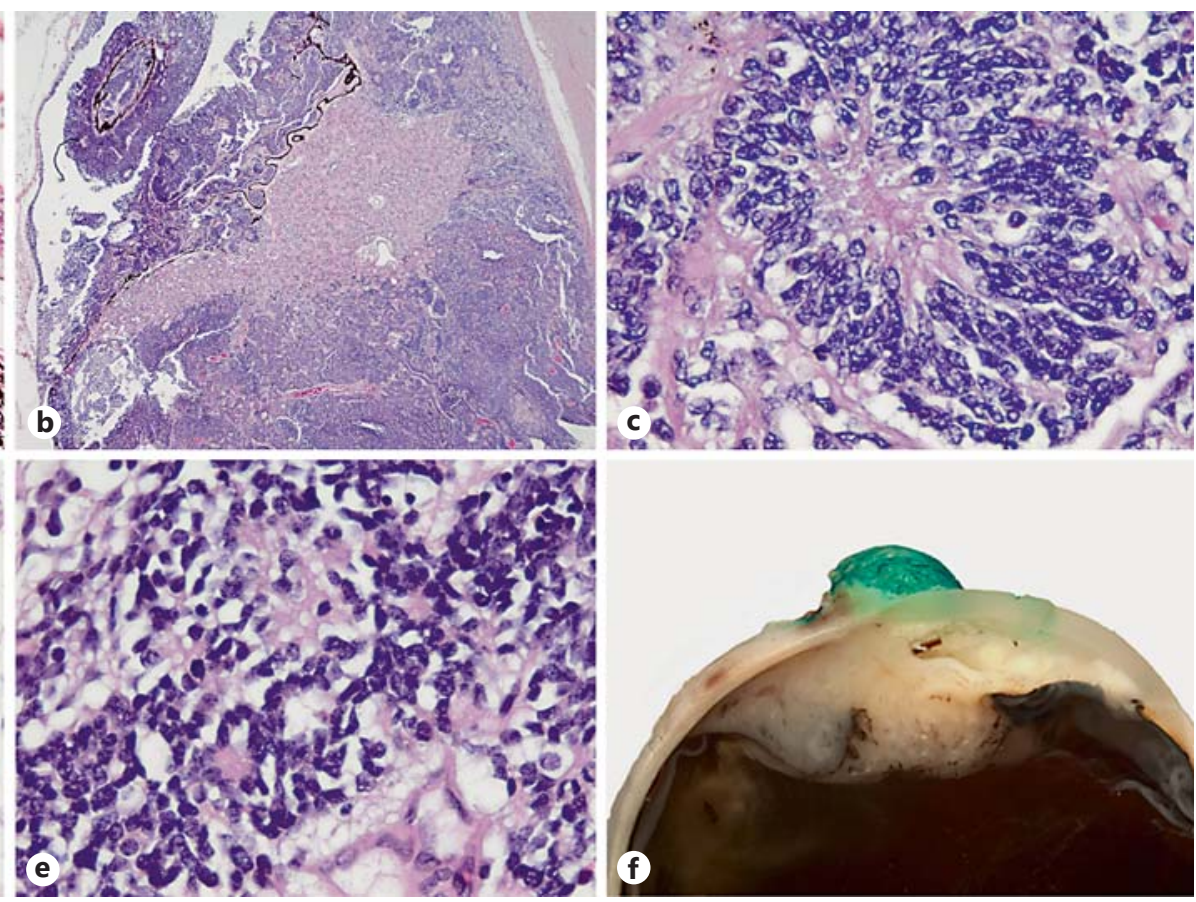

Table 1. Clinical and histopathological details of published adult cases of intraocular medulloepithelioma

\begin{tabular}{|c|c|c|c|c|c|c|c|}
\hline First author [Ref.], year & $\begin{array}{l}\text { Age, } \\
\text { years }\end{array}$ & Sex & Diagnosis & Treatment & $\begin{array}{l}\text { Follow- } \\
\text { up }\end{array}$ & Recurrence & Adjuvant \\
\hline Soudakoff, $1936^{\mathrm{a}}$ & 28 & $\mathrm{M}$ & Malignant nonteratoid & Enucleation & $13 \mathrm{mo}$ & No & No \\
\hline Zimmerman, $1972^{\mathrm{a}}$ & 32 & $\mathrm{~F}$ & Malignant teratoid & Enucleation & NR & No & No \\
\hline Broughton [8], 1978 & 41 & NR & Benign & NR & NR & NR & NR \\
\hline Carrillo, $1979^{\mathrm{a}}$ & 43 & $\mathrm{~F}$ & Malignant teratoid & Enucleation & $5 \mathrm{y}$ & No & No \\
\hline Shields, $1996^{\mathrm{a}}$ & 58 & $\mathrm{~F}$ & Malignant nonteratoid & Exenteration and RT & $2 y$ & Parotid metastasis & NR \\
\hline Husain, $1998^{\mathrm{a}}$ & 62 & $\mathrm{M}$ & Malignant nonteratoid & Neoadjuvant RT and enucleation & $6 \mathrm{mo}$ & No & No \\
\hline Jumper, 1999a & 45 & $\mathrm{M}$ & Malignant & Exenteration and adjuvant RT & NR & NR & NR \\
\hline Davidorf, $2002^{\mathrm{a}}$ & 23 & $\mathrm{~F}$ & Medulloepithelioma & $\mathrm{BT}$ and resection & $18 \mathrm{mo}$ & No & No \\
\hline Font [11], 2005 & 27 & $\mathrm{M}$ & Malignant nonteratoid & Resection and enucleation & $6 y$ & No & No \\
\hline Ali [15], 2013 & 67 & $\mathrm{~F}$ & Malignant non-teratoid & Enucleation & $5 y$ & No & No \\
\hline
\end{tabular}

mo = Months; $\mathrm{NR}=$ not reported $\mathrm{y}=$ years; $\mathrm{RT}=$ radiotherapy; $\mathrm{BT}=$ brachytherapy $\mathrm{CT}=$ chemotherapy; $\mathrm{LN}=$ lymph node.

${ }^{a}$ All referenced in Sosinska-Mielcarek et al. [9]. 
els enabled the identification of brain and ocular medulloepithelioma as separate nosologic entities $[5,6]$. Strict separation between a benign and malignant variant of intraocular medulloepithelioma does not reflect the clinical behavior of these tumors for as far as it can be deduced from small case series and case reports $[7,8]$. Criteria for malignancy have been pioneered by two early series reports from Andersen [7] and Broughton and Zimmerman [8], which thus far have not been correlated with clinical behavior. Andersen was of the opinion that all medulloepitheliomas should be considered as potentially malignant tumors which would have been reflected more clearly in a grading scheme than in a dichotomy into two types. Andersen accepted local invasion of the ciliary body and iris to be part of the benign spectrum and proposed pleomorphism, increased mitotic activity and extrascleral extension as a set of criteria for malignancy. Broughton and Zimmerman [8] introduced additional criteria for malignancy with areas of poorly differentiated neuroblastic cells, sarcomatous areas, or invasion of the uvea, cornea or sclera with or without extrascleral extension. In agreement with Andersen [7], I feel that medulloepitheliomas are most probably all potentially malignant tumors which would be reflected more clearly in a grading scheme than in a dichotomy. This notion is supported by the recently published molecular data on intraocular medulloepithelioma, which showed clustering in the same part of the dendrogram tree using unsupervised cluster analysis. There were no additional subclusters within the intraocular medulloepithelioma cohort separating histologically malignant from nonmalignant cases [6]. Neither could single nucleotide polymorphism array detect differences in copy number aberrations between benign and malignant medulloepithelioma. The fact that adult patients are more often diagnosed with malignant medulloepithelioma reflects the increased chance of malignant progression in time (table 1) [9-15]. Three documented cases of me- dulloepithelioma in adults have metastasized, which is a relatively high percentage when compared to the overall chance of metastasis for this tumor (table 1) $[8,16]$. True malignant behavior with metastasis has never been documented in tumors without extrascleral extension of the primary tumor or after invasive procedures $[7,8,17,18]$. A simple grading scheme of grade I tumors (current WHO benign designation), grade II tumors (tumor progression as evidenced with pleomorphism, increased mitotic activity and local invasion) and grade III tumors (tumor transformation to metastatic potential with extrascleral extension or metastasis) would be more reflective of the unifying hypothesis of a single classifying tumor entity liable to progression and transformation into a potentially metastasizing entity (fig. 1). Separate mentioning of sarcomatous areas may not be necessary as this already implies increased mitotic activity and pleomorphism. The presence of poorly differentiated neuroblastic cells also implies increased mitotic activity and thus requires no separate evaluation. The progression from benign to malignant medulloepithelioma has been documented once, further strengthening the argument [19]. The reduction of two classifying tumor entities into one and the introduction of a simple grading scheme might facilitate consistency in pathology reports and make the comparison for clinical follow-up and treatment decisions easier.

\section{Statement of Ethics}

The study is in compliance with the Declaration of Helsinki and was waived by the institutional committee on human research.

\section{Disclosure Statement}

The author has no sponsorship, funding or other conflicts of interest to disclose.
References
1 Campbell RJ, Sobin LH: Histological Typing of Tumours of the Eye and Its Adnexa, ed 2. Berlin, Springer, 1998.

2 Grinker RR: Gliomas of the retina, including the results of studies with silver impregnations. Arch Ophthalmol 1931;5:930-935.

-3 Bailey P, Cushing H: A Classification of the Tumors of the Glioma Group on a Histogenic Basis with a Correlated Study of Prognosis, ed 1. Philadelphia, JB Lippincott, 1926.
4 Louis DN, Ohgaki H, Wiestler OD, Cavenee WK: WHO Classification of Tumours of the Central Nervous System, ed 4. Lyon, International Agency for Research on Cancer, 2007. 5 Edward DP, Alkatan H, Rafiq Q, Eberhart C, Al Mesfer S, Ghazi N, Al Safieh L, Kondkar AA, Abu Amero KK: MicroRNA profiling in intraocular medulloepitheliomas. PLoS One 2015;10:e0121706. 
-6 Korshunov A, Jakobiec FA, Eberhart CG, Hovestadt V, Capper D, Jones DT, Sturm D, Stagner AM, Edward DP, Eagle RC, Proia AD, Koch A, Ryzhova M, Ektova A, Schuller U, Zheludkova O, Lichter P, von Deimling A, Pfister SM, Kool M: Comparative integrated molecular analysis of intraocular medulloepitheliomas and central nervous system embryonal tumors with multilayered rosettes confirms that they are distinct nosologic entities. Neuropathology 2015;35:538-544.

7 Andersen SR: Medulloepithelioma of the retina. Int Ophthalmol Clin 1962;2:483-506.

8 Broughton WL, Zimmerman LE: A clinicopathologic study of 56 cases of intraocular medulloepitheliomas. Am J Ophthalmol 1978;85:407-418

-9 Sosinska-Mielcarek K, Senkus-Konefka E, Jaskiewicz K, Kordek R, Jassem J: Intraocular malignant teratoid medulloepithelioma in an adult: clinicopathological case report and review of the literature. Acta Ophthalmol Scand 2006;84:259-262.
Sayed BA, Sahgal KN, Desai VK: Medullo-epithelioma. Br J Ophthalmol 1962;46:58-60.

11 Font RL, Rishi K: Diffuse retinal involvement in malignant nonteratoid medulloepithelioma of ciliary body in an adult. Arch Ophthalmol 2005;123:1136-1138.

12 Pushker N, Khuraijam N, Sen S, Bajaj M, Mehta M: Medulloepithelioma of the ciliary body associated with massive intravitreal hemorrhage in an adult. Can J Ophthalmol 2008;43:253-254.

13 Meel R, Chawla B, Mohanti BK, Kashyap S, Bakhshi S: Ocular medulloepithelioma chemosensitivity. Ophthalmology 2010;117: 2440.e2441-e2442.

14 Singh G, Gupta R, Kakkar A, Iyer VK, Kashyap S, Bakhshi S, Mathur SR: Fine needle aspiration cytology of metastatic ocular medulloepithelioma. Cytopathology 2010;22:343345 .
15 Ali MJ, Honavar SG, Vemuganti GK: Ciliary body medulloepithelioma in an adult. Surv Ophthalmol 2013;58:266-272.

16 Kaliki S, Shields CL, Eagle RC Jr, Vemuganti GK, Almeida A, Manjandavida FP, Mulay K, Honavar SG, Shields JA: Ciliary body medulloepithelioma: analysis of 41 cases. Ophthalmology 2013;120:2552-2559.

17 Canning CR, McCartney AC, Hungerford J: Medulloepithelioma (diktyoma). Br J Ophthalmol 1988;72:764-767.

18 Viswanathan S, Mukul D, Qureshi S, Ramadwar M, Arora B, Kane SV: Orbital medulloepitheliomas - with extensive local invasion and metastasis: a series of three cases with review of literature. Int J Pediatr Otorhinolaryngol 2008;72:971-975.

19 Lindegaard J, Heegaard S, Toft PB, Nysom K, Prause JU: Malignant transformation of a medulloepithelioma of the optic nerve. Orbit 2010;29:161-164. 